\title{
SELF-MANIPULATION AS A FORM OF DESIRE FULFILLMENT IN "CATCH ME IF YOU CAN" NOVEL BY FRANK W. ABAGNALE JR
}

\author{
Elfi Rahmi \\ Putera Batam University (UPB), Batam, Kepri, Indonesia \\ elfiazela04@gmail.com \\ Tomi Arianto \\ Putera Batam University (UPB), Batam, Kepri, Indonesia \\ Tomy2088.ta@gmail.com
}

\begin{abstract}
Every human being needs the need to be able to continue living one of the things that is needed is the esteem needs. This study aimed to find the esteem need from Frank William Abagnale in Catch Me If You Can novel by Frank W. Abagnale Jr. which is a real story of the main character, Frank W. Abagnale. This novel was once the best seller in New York published in 1980 which tells the story of a person who is an expert in fake checks, manipulate identities and run away to fulfill life's needs and recognition of the status, achievements and identity of a character. The theory used in this paper is based on Abraham Maslow's theory. Abraham Maslow described the needs of human life in the form of a Pyramid, where the most basic parts are the most important needs in human life. This research that used by researcher is a qualitative research. The process of presenting research results uses informal methods by describing them through words. From the process of data analysis, it can be found that the main character Frank Abagnale in the novel "Catch Me if You Can" continues to struggle to fulfill his life needs as a human. It all started from the needs of Frank who wanted to meet the needs of self-esteem and recognition from people around his environment.
\end{abstract}

Keywords: Hierarchy of needs, esteem need, psychological approach

\section{INTRODUCTION}

Human being need to feel respected. This was something that many people needs in their lives. Everyone who is around us had some reason to get a good respect from everyone but not everyone will give a good respect. There are some reasons why people want to get respect, including esteem need. Many people believe that esteem need or dignity of a person is an outward right that is highly upheld by someone. Because of that, when people do not get respect, there will be negative things in the community.

Yoga Cahyadi is one case of the example of esteem need in our country based on CNN Indonesia (2014). When 
he presented in forum, he bullied by his friends in party. His friend called him "kebo" or "buffalo". He did not accept and felt hurt by the ridicule. He felt sad and depressed because he was not strong enough to hear all scorn from his friends. Before Yoga died, he wrote a status in his twitter account talked about his feeling. Finally, he decided to end his life by crashing his body into a train. From the case above, esteem need really relates to all people. There is no people wants to get bullied no matter how little the bully is. Even though someone only called "kebo", it makes somebody angry, sad and disrespectful.

From the phenomena, esteem need was part of the needs of human nature. As all known in America, there was a famous expert which explains about esteem need. He is Abraham Maslow. From the five hierarchy of need of Maslow concepts, the esteem need was the fourth level of hierarchy of needs. According to Maslow (2012) said the high level in the concepts hierarchy was self-actualization contained certainly selfishness and selfprotectiveness, and also sure promised of violence was needed. Hence, the self-actualization needs demanded not only as an essential aspect of human life. The conflict usually were needed to be involved to achieve selfactualization. Furthermore, esteem need is the process of human to get an ability, great achievement, social status in community and self- actualization. Based on the knowledge of esteem need as said by Maslow (2012) in his theory, it known that some authors fill their literary work that can be useful for researcher. Then the researcher and the reader understand that make an analysis in research.

One of the novel that raised an issue about esteem need can be seen in the novel "Catch Me If You Can" by Abagnale (1980). The novel is the bestseller book by Abagnale in the year of its publication. This novel also ever raise up as the best comedian action criminal movie on 16 December 2002 in Los Angeles which the major actor is Leonardo DiCaprio. This novel was made into a movie with the same title that got a possitive review from readers and journalists. Gillard (2015) Sugeested that the novel really incredible comedian criminal. Moreover, this novel after raised up to movie became the trending topic in New York Times at the first week launching.

The esteem need found in this novel based on the quotation. Because of that, the researcher contributed to develop the analysis in the novel to know more deeply and explore about esteem need that exist in the main character in this novel. There were some researchers that contribute in developing the idea to make an analysis used a hierarchy of need. The article is written by Arianto, T., \& Ambalegin, A. (2019) which analysed the attempted suicide caused by a lack of love belonging in Jhumpa Lahiri's story. This study also used Maslow's theory about the hierarchy of needs. The next research was written by Kinanti, A. L., \& Daulay, R. (2020) in their article which discussed the experience of children's violence on the psychological impact they get. This study took the data source from the novel Eleanor and Park which is subject to abusive treatment of children. The article written by 
Arianto, T., \& Ambalegin, A. (2020) which used Lacan's psychological theory can also be used as a reference in psychological analysis. This study tried to reveal that fantasy works such as in the iron man story are psychologically escaping to release all life's problems. Finally, Herdayanti, K., \& Satria, R. (2021) articles contributed to the application of psychological theory to the lady bird movie.

There were some similarities such as used the Maslow theory and the object of the research. The difference between previous researches was the novel. The researcher analysed "Catch Me If You Can" Novel by Frank to fulfil the esteem need by Abagnale and the previous research used Margaret Tate's on the proposal movie to show the esteem need. From the journal, it concluded that there was a connection with this research. It can be a reference to the used of Maslow's theory in achieving needs based on the level.

From the explanation above, these previous research had explained about esteem need in hierarchy of need by Maslow. Therefore, this research gave a good contribution and brought idea to the researcher about esteem need. Although those previous research used the same theory, but there were some differences between the researcher. In this research, the researcher attempt to analysis esteem needs of the main character in the novel "Catch Me If You Can" by Frank W. Abagnale Jr. This novel is comedian action criminal genre that available to make an analysis. Finally, the researcher decided to analysis this novel as the entitled of thesis to found the esteem need in the main character and the effort of the main character to fulfil the esteem need

\section{REVIEW OF RELATED LITERATURES}

In analysing a novel for a thesis, especially for English literature, the researcher must use theory as an approach. The theory itself had function to support the thesis. When the readers read the thesis, they believed that the thesis had strength. Furthermore, without using theory the readers will doubt whether the thesis has basis to be believed or no. In literature, there were many kinds of theory that used to analyse psychology. One of the famous expert was Freud (2008) said that human had three component which could not separate from human mind: id, ego, superego. Then Carl Jung (1980) also regarded the psyche as made up of a number of separate but has interacting systems.

According to Maslow (1954) human needs could arrange themselves in hierarchies of pre-potency. Human would continue their live to complete the need that usually appear in their mind. The need also treated if they were isolated or discrete. And every condition that drive human mind, it would be related with the satisfaction and dissatisfaction of other drives. From the explanation above means that human need related to hierarchy of need as the unit which could not separate from human circle live. Maslow (2012) considered one of the famous leading architects of humanistic psychology proposed a hierarchy of needs into five categories: starts with the basic need were physiological needs, safety needs, belongingness and love, esteem needs, and until the highest level self-actualization. Thus, all 
concepts could apply into human life to fulfil their needs. The details explanation below about five hierarchies of needs:

Abraham Maslow is a father of spiritual and humanistic psychology that proposed the hierarchy of need. The theory that developed by Maslow and also one of the famous theory like other experts such as Sigmund Freud and Carl Jung. The concept of Maslow theory in hierarchy of needs often portrayed in the shape of pyramid.

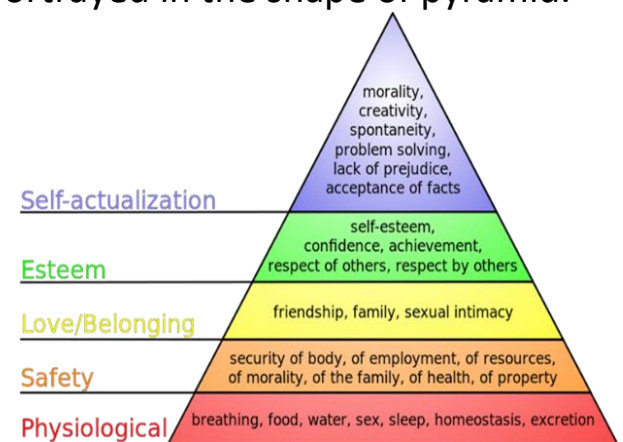

Figure: Pyramid of Hierarchy of Needs by Abraham Maslow

The first stage described about basic need in human nature. The basic need should has a strong foundation for human to continue their live. Maslow described them as pyramid, the base stage included of physiological needs and self-actualization needs at the top stages. Because of Maslow had arranged hierarchy of need from the lowest to the highest needs. The hierarchy of need that formulated by Maslow has five stages. All the stages had a different function based on human needs.

The five stages in hierarchy of need concluded physiological needs, safety needs, love and belonging, esteem needs, and until the highest level selfactualization. From the stage above, Maslow wanted to know and understand what something that could motivate people. He believed that human always has a motivation to drive them to get fulfil the needs in conscious or unconscious desires. He stated that human would be motivated to achieve certain needs. When one need was fulfil, a person will continue to find the next one, and so on. Maslow suggested that the basic stage of needs should be fulfil before the individual would be more strongly desire or more focus to drive the motivation upon the secondary or higher stages needs.

\section{METHOD OF RESEARCH}

There are two types of research designs; they are quantitative and qualitative research. Qualitative method is a method that focused in explain data descriptively. While Quantitative method is a method that focused in collecting numerical data to explain phenomenon that particular. Furthermore, according to Ratna (2012) explained that qualitative research is research contains natural data summarized in a literary work and involves elements of culture. Qualitative research always maintains the nature of the values in it which are then analyzed. Thus, researchers used a qualitative method in analyzing this study that followed the steps and the research design process began with the phenomenon found by researchers when reading the novel Catch $\mathrm{Me}$ if You Can by Frank W. Abagnale.

The object of this research is esteem needs. The esteem need were analyzed based on Maslow (2012) theory. The esteem need has two specification. The researcher was analyzed in a novel entitled an analysis esteem needs of the main character in the novel "catch me if you can" by 
frank w. abagnale jr: psychological approach.

\section{RESEARCH ANALYSIS AND FINDING}

4.1. Esteem Need and Effort to Fulfill The Esteem Needs

a. Un-confidence

Un-confidence is part of the attitude that is usually owned by everyone who arises from the problem in a person. An un-confidence is usually influenced by several factors including family factors, environmental factors and problems within a person. As in the quotation of the novel catch novel if you can by Frank, which described Frank's lack of confidence as a villain can be seen from the quotation below:

"I'd have to change my name, acquire bogus identification and set up a bank account under my alias before I could operate. It all seemed complex and danger-ridden to me. I was a successful crook. I wasn't yet a confident crook".(Abagnale, 1980, p. 41)

From the quotation above Frank changed his name before making a bank account with the aim of disguising it to be safer and avoiding danger. After that in the statement above said that Frank was a successful person as a criminal. But in the next sentence he felt he was not yet confident of being a criminal. There was something really contrary to Frank. Frank's attitude of insecurity arose because Frank didn't really feel like a criminal. If Frank really wanted to be a criminal, Frank will not say that he doesn't believe in being a criminal. According to Maslow the character Frank has an un-confidence feeling in himself. There were doubts that arise from his actions. So Frank was not able to fulfill the need for his confidence to become a real villain.

b. Self- esteem

Someone usually can lose their self-esteem if they were not feel comfortable with the situation in society. It was like the situation that happened to Frank. Frank utteranced his feeling into the quotation below:

"The alternative was to leave New York, and the prospect frightened me. That still-remote corner of the world suddenly seemed chill and friendless. In Manhattan, despite my brash show of independence, I'd always clutched a security blanket. (Abagnale, 1980, p. 40)

Frank began to feel afraid with the situation in New Yok. He runned to leave the city soon. Because he known that if he lived a long time in New York it would become dangerous for his security. He said that in Manhattan he can show of his independence. It means that in that city he can more secure than in New York. Furthermore, frank has not able to fill the self-esteem because he was not finding the ways to solve his problem. He only stuck in that situation. So he failed to fill the needs.

c. Un freedom

In generally un-freedom is the situation that described human cannot do something based on their own desire. They stuck in their problem so they cannot get the way to run out again. The un-freedom usually happen when someone is caught and stayed in prison. Prison is a place for people that do criminal. This situation can be seen from the sentences below:

"I was kept six days in Montpellier, during which time several lawyers appeared to offer their services. I selected a middle-aged man whose 
mannerisms and appearance reminded me of Armand, although he frankly stated he didn't think he could win me my freedom. "I have gone over all the police documents, and they have you dead to rights," he commented. "The best we can hope for is a light sentence." (Abagnale, 1980, p. 334)

Frank held in Montpellier prison as long six days. Some lawyer comes to him to offer their service. Frank chooses one of middle-aged men whose has a character like Armand. Frank wants to get his freedom again. However, it is impossible for him because his criminal is serious case. So the conclusion, frank cannot get his freedom.

4.2. The effort of the main character to fulfill the esteem needs by Frank Abagnale

a. Confidence

Confidence became a part of the attitude that was usually owned by everyone. Confidence started with one's self-concept when he wanted to appear different from usual. Confidence also courage to take the right actions and decisions. As in the novel CMIYC by Frank. The quote below illustrated Frank's confident attitude when wearing his pilot's uniform. The esteem needs can seen from the quotation below:

"Satisfied with my appearance, I picked up my bag, left the room and two minutes later was standing in front of the cashier's cage. Good morning, Captain," said the cashier in warm tones. The markings on my uniform identified me as a first officer, a co-pilot, but the French are like that. They tend to overestimate everything save their women, wine and art. (Abagnale, 1980, p. 5)

From the quotation above was taken when Frank came out of his room and picked up his bag. He feels satisfy when he wore uniform as co-pilot. The cashier told him in warm tones. The copilot uniform that Frank wore identify himself as the person that has dignity. He got the confidence in himself to fulfill the esteem needs. So Frank's confident attitude earned him his own satisfaction. Many people who saw the pilot's uniform made Frank feeling proud of his new identity as a pilot. The conclusion from the quotation that related to Maslow theory. There were a connection between confident with the esteem need. Because confidence is physical mentally when people got the confidence they also get their esteem. So finally, Frank can fulfill his needs by showing his confidence in the pilot uniform.

b. Ability and Skill

Everyone certainly has ability in a certain field. The ability of each person is different depending on what type of ability which people has. In this story, there is people who have skill as a reliable con artist like in the novel quote below that draws the figure of Frank who has amazing skill:

"I was a swindler and poseur of astonishing ability. I sometimes astonished myself with some of my impersonations and shenanigans, but I never at any time deluded myself. I was always aware that I was Frank Abagnale, Jr., that I was a check swindler and a faker, and if and when I were caught I wasn't going to win any Oscars. I was going to jail". (Abagnale, 1980, p. 10) 


\section{s Science Htumanity Pournal}

The scenes above, clearly explained about Frank ability. He said that he was a great imposter with extraordinary abilities. And Frank never deceived himself. He was always aware of his actions and who he is. Frank's fraud did only for his personal pleasure. He was a real young boy that many surprise in all his crime. According to Maslow that supposes the hierarchy of needs. The relationship of ability and esteem is closely. It is something that cannot separate from both of them. Because ability can improve of the esteem need by the character. So the conclusion Frank success to cover up his weaknesses with the ability to show his skill to be a check swindler and a faker. He also not yet catch by the police.

c. Adequate Income

Money is part of human needs. For to get the money, everyone of course has their own way. No exception that is the act of manipulate self-identity. Everyone knows that fulfilling their needs will certainly do whatever acting as Frank did:

"Wilcox fulfilled his promise. He arranged a job interview for me with the state attorney general, who, Wilcox's recommendation, hired me as an assistant. My salary was $\$ 12,800$ annually. I was assigned to the corporate law division, one of the AG's civil departments." (Abagnale, 1980, p. 156)

Frank worked as assistant. He can get the job because Wilcox is recommendation him to joint in the division. Then Frank got the high salary in every year. He also felt this condition really fantastic. Remembering he actually was not even finish high school or the college. But his acting can make somebody trust to him like Wilcox. On the other hands, finally Frank fulfill his need. It is can be seen from his statement above. Related to Maslow concept in hierarchy of needs. Frank is only wants to fulfill his financial even though he lies Wilcox.

In the next story, Frank also gets much income within when he hired as a teacher as in the quote below:

"I was hired within the hour to teach two six-week semesters during the summer at a salary of $\$ 1,600$ per semester. I was assigned to teach a ninety-minute freshman course in the morning, three days a week, and a ninety-minute sophomore course in the afternoon, twice weekly. (Abagnale,1980, p. 169) From the quotation above frank disguised as a teacher at the colleges. Frank gets high salary during teaching in the college. He only teaches the class into two semesters. Again and again Frank performs to be a professional teacher who tries to teach all his student perfectly. The fact, he also a student that not finish high school. But Frank always has some tricks to manage all his crime for. Therefore, the way that Frank uses to meet his needs is by pretending to be a lecturer. The trick turned out to be successfully used by Frank to get income. So the theory by Maslow connects to Frank's character in the novel. Which is Frank makes himself to get the adequate income for fulfill the fourth stages in hierarchy.

\section{d. Achievement}

There is nothing impossible for somebody to get the high achievement in their live. Even the way to get the achievement and popularity getting by criminal. This is like Frank statement 
that utterance his feeling into the novel below:

"I faced myself with some unpleasant truths. I was a crook. Nothing more, nothing less. In the parlance of the streets, I had become a professional paperhanger. That didn't bother me too much, for I was a successful paperhanger, and at the moment to be a success at anything was the most important factor in the world to me. (Abagnale, 1980, p. 39)

From the quotation above, Frank realized that he is a criminal person. Yeah, Frank is a professional criminal in swindle paper checks. He also to be a successful paperhanger at the time. Then the moment is always remembering by him. Frank said that the most important thing is able to succeed in any field. It is to be one spirit for him during becomes a check forgery. The relationship between achievement and esteem can be seen from the word "successful". Because the word "successful" described someone has already fulfill the needs. The word also explained that Frank increases his level in social. So the quotation has a correlation with Maslow concepts. Which is Frank has been get the achievement in fake live.

e. Respect from others

After people can fulfill their achievement. They usually want to get respect from other people. Of course, the respect is one of the most important point in society. It is like the scene from the novel Catch me if you can:

"I felt great in my Pan Am pilot's uniform as I walked into La Guardia Airport. I obviously was commanding respect and esteem. Men looked at me admiringly or enviously. Pretty women and girls smiled at me. Airport policemen nodded courteously. (Abagnale, 1980, p. 69)

From the quotation above, it is explained that Frank walked out from the La Guardia Airport. He gets the positive response from other people and from other airline crews around the Airport exactly. This because Frank to be confidence with his new identity as pilot Pan Am. He feels great while he is wearing Pan Am pilot's uniform. Every people in the airport looked him amazed and friendly. And this moment as the best acting for him. No one know the originality identity by Frank when he performed as a pilot. The fact, he really gets the respect and esteem from other people. From the analysis above, the concept of hierarchy of needs by Maslow is available with the novel. So the main character can fulfill the esteem need which is he gets the respect from other people after he changed his identity as pilot. Even though Frank is a fake pilot who never ever flies a plane.

Although Frank has a fake identity as pilot. He always success to get positive response from other people around him. Frank has a magnet to make people interesting with his performance.

"Pilots and stewardesses smiled, spoke to me or lifted a hand in greeting as they passed. Every man, woman and child who noticed me seemed warm and friendly. (Abagnale, 1980, p. 69)

The scene above tells that Frank receives respect from others such as pilots and stewardesses airlines. Because of the Pan Am airline pilot 
uniform that he was wearing, everyone looked at it with awesome and full of charm and was even more childlike and even looked at him with admiration. Frank feels even more convinced that the Pan Am pilot uniform becomes the biggest magnet to get respect from others. In real phenomena in society connect to the novel when someone gets praise and respect from other people. They will definitely feel proud of the respect. And the end, from the analysis the quotation, the main character Frank gets to fulfill of the esteem needs.

After Frank success to steal attention from other people as pilot in Pan Am airlines. Frank continues to the other profession. Frank uses different method to make people don't know who he is. Frank always performs as a professional in every act. Then Frank success to get the respect from Brenda and Dr. Carter. They respect Frank more than a real doctor:

"Pilots and stewardesses smiled you're great, Frank," said Brenda. "Young Dr. Carter especially thinks you're terrific. I heard him telling some friends of his visiting from Macon how you let him get real practice, that you just come in, get his comments on the situation and let him proceed. He says you make him feel like a practicing doctor." (Abagnale, 1980, p. 136-137).

Brenda tells to Frank that Dr. Carter appreciate to him. Both of them think that Frank as a real doctor. But the fact, Frank is fake doctor. Frank not only receives more respect from them but also get their positive image as young doctor. He recognize professional in his work. Although he is a fake doctor and never becomes a real doctor. In the other hand, Frank success to complete his esteem need while he is acting as a doctor. The conclusion from three quotation above based on the theory that used by the researcher, the most important needs that the main character in the novel Catch me if you can is respecting from other people. Because in each quote state that Frank always wants to get respect and Frank can complete all the needs.

f. Prestige or Reputation

Prestige or reputation is very important for everyone. The prestige can also increase confidence and human can get high value in the eyes of the community. For examples of prestige that can make self-esteem increase can be seen from the goods or clothing. It is like pilot uniform that Frank is wearing.

She shrugged. "It doesn't matter," she said. "You're a Pan Am pilot in uniform, and any airline here will take your personal check as a courtesy. They do that at Kennedy, don't they?" (Abagnale, 1980, p. 80)

His friend said that you are Pan Am pilot and you wear the pilot uniform. There is no problem. It is obviously explain that Frank has a high identity as a pilot. No one will ask to him again because he performs as a real pilot. In the scene above, Frank wants to cash the check, but he feels hesitate to do that till his friend make himself back to trust again. Frank's uniform actually identify himself as a pilot. The bankers certainly will received the check. This situation indicates that Frank has a reputation as a pilot and is certainly known for the uniform he wears. So in the other hand, Frank actually was fulfilling the esteem need with his reputation as a pilot and people easily 
recognized him with just the uniform he wore.

Frank is one of the popular boy in his division. He also is a young bachelors in the campus.

"I was popular with the young bachelors in the division. I still had over $\$ 20,000$ in my boodle and I spent it freely on the friends I made on the AG's staff, treating them to dinners in fine restaurants, riverboat outings and evenings in posh night clubs. (Abagnale, 1980, p. 157)

The quotation above showed in the campus when Frank said that he was famous as a young bachelors in his division and he invited his friend to dinner at a restaurant. From the quotation can be concluded that Frank has a popular reputation in the campus. So the prestige by Frank can be seen from the word "popular". He has a reputation and prestige. Therefore, Frank has been complete the needs and his reputation in the community.

\section{g. Appreciation and Recognition}

The appreciation and recognition were to be the important need for humans. It was same with Frank's live who he wanted to get the appreciation from other. In short, this described about Frank story that found the needs. Frank was a person who was very smart to attract the attention of the world. He received many compliments from important parties in America. Frank's life journey was a crime adventure that is amazing and also impressive. That's because Frank's intelligence in analyzing checks and also checks forger. Frank has been in prison many times. And finally he can be free on parole. That's because he behaved well while in prison. After he got out of prison, Frank found it hard to get a job. Because Frank is a former American federal prisoner. Frank always gets a rejection from his employer who knows the true background of Frank's life. But Frank never felt discouraged by all these rejections. Until finally Frank realized the instinct of talent he had. Frank thought that if he used his expertise it might help others not be fooled. It was shown below:

"Abagnale approached a suburban bank director, outlined what he had in mind and detailed his background as a master bilker of banks. "At the moment I have no slide presentations or anything," said Abagnale. "But I'd like to give a lecture to your employees for one hour after closing. If you think my lecture is worthless, you owe me nothing." (Abagnale, 1980, p. 419)

From the scene above. It was taken when Frank tried to approaches a bank director. He offered his knowledge to teach some of employee bank. He explained the detail background about what he had in mind and his detailed background skill. Here the Frank tried to get his appreciation with more closely to bank director.

Continued to next quotation. Obviously explained that Frank had been completed his esteem need as a useful people in the future time:

"Today, three years later, Frank Abagnale is one of the nation's most popular crime authorities, with offices in both Houston and Denver, a highly-trained staff, and gross revenues approaching \$3 million. He still leads a life on the fly, constantly criss-crossing the nation to present seminars, give lectures or to appear on various television panels. Frank 
Abagnale leads a very satisfying life." (Abagnale, 1980, p. 420)

From the quotation above shown that Frank actually has success to complete all his need. He became the most popular crime authorities and to be a rich man that has two office and high salary till three million dollar. After Frank through all the dark period in his live in result Frank appeared as new persons which more useful. Frank satisfied with his life in the future time and because of his expertise. Finally, Frank was instrumental in solving all cases of fraud that occurred in several countries specifically for checks forger. According to Maslow theory said that people will fulfill their esteem need after they got the appreciation from other. So it was to be the important point in this level.

\section{CONCLUSION}

Esteem need is a part of human nature that has essential element in human life. The theory that supposed by Maslow available with the novel to fulfill the fourth stages in main character. After analyzing the esteem need by using a novel Catch Me If You can. The researcher made the conclusion that the fourth stage of esteem need was fulfilled by Frank. He is able to meet his esteem need through all a long journey to find his need.

\section{REFERENCE}

Abagnale, F. (1980). Catch me if you can. (S. Redding, Ed.). United State of America: New York. https://doi.org/79-91619

Aishwarya, \& Shahrawat, R. (2017). Application of Maslow ' $s$ hierarchy of needs in a historical context: Case studies of four prominent figures. Scientific Research Publishing, 939-954. https://doi.org/10.4236/psych.201 7.87061

Aras, G. (2015). Personality and Individual Differences: Literature in Psychology- Psychology in Literature. Procedia - Social and Behavioral Sciences, 185, 250-257. https://doi.org/10.1016/j.sbspro.2 015.03.452

Arianto, T., \& Ambalegin, A. (2019). Suicide Experiments Due to Unmet Love Needs in Jhumpa Lahiri's Hell-Heaven Story. IdeBahasa, 1(1), 41-50. link https://jurnal.idebahasa.or.id/inde x.php/Idebahasa/article/view/3

Arianto, T., \& Ambalegin, A. (2020). Escaping of Lackness Trough Fiction for Desire and Emptiness Fulfilment. IdeBahasa, 2(1), 49-58. link

https://jurnal.idebahasa.or.id/inde x.php/Idebahasa/article/view/37

Aruma, H., \& Enwuvesi, M. (2017). Abraham Maslow's Hierarchy of Needs and Assessment of Needs in Community Development, 5(7), 15-27.

Blaskova, M., \& Grazulis, V. (2009). Motivation of human potential: Theory and practice. Vilnius: Monograph.

Branden, N. (1992). The power of selfesteem. Deerfield Beach, Florida: Health Communications.

Fanaj, N. (2015). A systematic literature review on self-esteem and selfesteem and psychological wellbeing in Kosovo. Human And Social Sciences at the Common Conference, (November 2014). Retrieved from 
https://www.researchgate.net/pu blication/269394609\%0AA

Faruk. (2014). Pengantar sosiologi sastra dari strukturalism genetik sampai post-modernisme. Yogyakarta: Pusaka Pelajar

Freud, S. (2008). Commentary on Freud: "the ego and the id." in self and subjectivity (pp. 195-205). https://doi.org/10.1002/97804707 74847.ch15

Moss, D. (2011). The roots and geneology of humanistic psychology. Retrieved from https://www.aapb.org/i4a/pages/i ndex.cfm?pagel $\mathrm{D}=3394$

Goldstein, K. (1940). Human nature : In the light of psychopathology (first Edit). New York: Shocken Books. Retrieved from https://libgen.is/search.php?req=k urt+goldstein\&lg_topic=libgen\&op en $=0 \&$ view $=$ simple $\&$ res $=25 \&$ phras $\mathrm{e}=1 \&$ column $=$ def

Grinstead, D. (2015). The psychology of Abraham Maslow. Psychology, (April), 1-16. https://doi.org/10.13140/RG.2.1.4 697.0407

Herdayanti, K., \& Satria, R. (2021). PSYCHOLOGICAL CONFLICT OF THE MAIN CHARACTER REFLECTED IN LADY BIRD MOVIE: English. JURNAL BASIS, 8(2), 231-238. link https://ejournal.upbatam.ac.id/in dex.php/basis/article/view/3766
Kinanti, A. L., \& Daulay, R. (2020). Child Abuse Experienced By The Main Character In Rainbow Rowell's Eleanor And Park: A Psychosocial Analysis. IdeBahasa, 2(2), 155-164. link

https://jurnal.idebahasa.or.id/inde x.php/Idebahasa/article/view/48

Maslow, A. (1954). Motivation and personality (2scnd edit). New York: Harper and Row Publisher.

Maslow, A. (2012). Towards a psychology of being (eBook edit). New York: Start Publishing LLC Copyright.

Putri, A., \& Megah, S. I. (2017). The esteem need of Margaret Tate' $s$ on the proposal movie. Journal Anglo-Saxon, VIII(1), 34-46. https://doi.org/ISSN: 23015292

Ratna, N. K. (2015). Teori, Metode, dan Teknik Penelitian Sastra. Yogyakarta: Pustaka Pelajar.

Sudaryanto. (2015). Metode dan aneka teknik analisis bahasa. Yogyakarta: Sanata Darma University Press.

Vanti, A., \& Sulistyorini, H. (2013). Magwitch' $s$ self esteem motive described in Charles Dickens' $s$ great expectations. Journal Article, 1-18.

Walborn, F. (2014). Religion in personality theory (pp. 255-278). New York: Elsevier Inc. https://doi.org/10.1016/B978-012-407864-2.00012-6 